\title{
CCND1/FSTL3 Fusion Gene
}

National Cancer Institute

\section{Source}

National Cancer Institute. CCND1/FST L3 Fusion Gene. NCI Thesaurus. Code C99370.

A fusion gene that results from a chromosomal translocation $\mathrm{t}(11 ; 19)(\mathrm{q} 13 ; \mathrm{p} 13)$ which places the CCND1 gene on the 5' side of the FST L3 gene. This rearrang ement may be associated with B-cell chronic lymphocytic leukemia. 